\title{
Contributions of bark and tension wood and role of the G-layer lignification in the gravitropic movements of 21 tropical tree species
}

\author{
Barbara Ghislain $^{1}$ (I) $\cdot$ Tancrède Alméras $^{2} \cdot$ Jonathan Prunier $^{1} \cdot$ Bruno Clair $^{1,2}$
}

Received: 28 March 2019 / Accepted: 6 November 2019 / Published online: 10 December 2019

(C) The Author(s) 2019

\begin{abstract}
- Key message Gravitropic movements in angiosperm woody stems are achieved through the action of bark and/or wood motor, depending on the bark and wood fibre anatomy (with trellis structure or not; with G-layers or not). Bark motor is as efficient as wood motor to recover from tilting in young trees of 21 tropical species.

- Context Angiosperm trees produce tension wood to control their orientation through changes in stem curvature. Tension wood is classified into 3 anatomical groups: with unlignified G-layer, with lignified G-layer and without G-layer.

- Aims This study aimed at assessing whether this anatomical diversity reflects a diversity in efficiency of gravitropic movement. - Methods The study was conducted on tropical seedling from the three anatomical groups. Seedlings were staked and grown tilted. At the end of the experiment, changes in curvature when releasing the stem from the stake and when removing bark were measured. Three parameters were computed to compare the global efficiency of gravitropism (stem gravitropic efficiency) and the specific efficiency of motor mechanism based on wood (maturation strain of tension wood) and bark (standardized debarking curvature).

- Results The maturation strain of tension wood was similar between species with unlignified and lignified G-layer. Species without G-layer exhibited low maturation strain and large debarking curvature, showing they rely on bark for gravitropism. Bark and wood achieved similar motor efficiency.

- Conclusion Lignin does not affect the generation of tensile stress in the G-layer. Bark can be as efficient as wood as a motor of gravitropic movements.
\end{abstract}

Keywords Bark · Biomechanics $\cdot$ G-layer $\cdot$ Lignification $\cdot$ Tension wood $\cdot$ Tropical rainforest

\section{Handling Editor: Jean-Michel Leban}

Contribution of the co-authors B.C. initiated the study. BG collected the seeds and seedlings. B.G., J.P., T.A. and B.C. designed the experiments, B.G. and J.P. performed the experiments. BG performed data processing and statistics. All the authors discussed and interpreted the results. B.G. wrote the first version of the paper. BG, TA and $\mathrm{BC}$ discussed and modified the text. All co-authors gave their final approval for publication.

\section{Barbara Ghislain}

barbara.ghislain@gmail.com

1 CNRS, UMR EcoFoG, AgroParisTech, Cirad, INRA, Université des Antilles, Université de Guyane, 97310 Kourou, France

2 Laboratoire de Mécanique et Génie Civil (LMGC), Université de Montpellier, CNRS, 34095 Montpellier, France

\section{Introduction}

The vertical orientation of plant stems is highly instable. It can be easily disturbed, for example by wind, animals, falling trees or debris. Growth itself is a source of disturbance: because of gravity, the increasing self-load of the plant tends to bend stems downwards. To cope with these situations and control or restore vertical growth in the field of gravity, plants need an active motor system (Moulia et al. 2006) to correct mechanical disturbances. In trees, this motor function is taken on by secondary growth, involving wood and/or bark. When needed, woody stems of most angiosperms produce a special tissue in their wood called tension wood (Dadswell and Wardrop 1955; Côté et al. 1969). This tissue is located on the upper side of the cross section of a leaning axis and generates tensile forces during wood maturation (Archer 1986) and/or interacts with bark to generate strong tensile forces in bark (Clair et al. 2019; Fig. 1). Production of tension wood is often accompanied with 
Fig. 1 Schematic representation of the active motor systems to upright angiosperm trees. High tensile stress (arrows) is generated in wood (a), wood and bark (b) or bark (c). Fibre cell wall is composed of several sub-layer, ML, middle lamella; $P$, primary cell wall; $\mathrm{S}_{1}, \mathrm{~S}_{2}, \mathrm{~S}_{3}$, G, sub-layers of the secondary wall. G-layer is either lignified (red) or unlignified (blue)

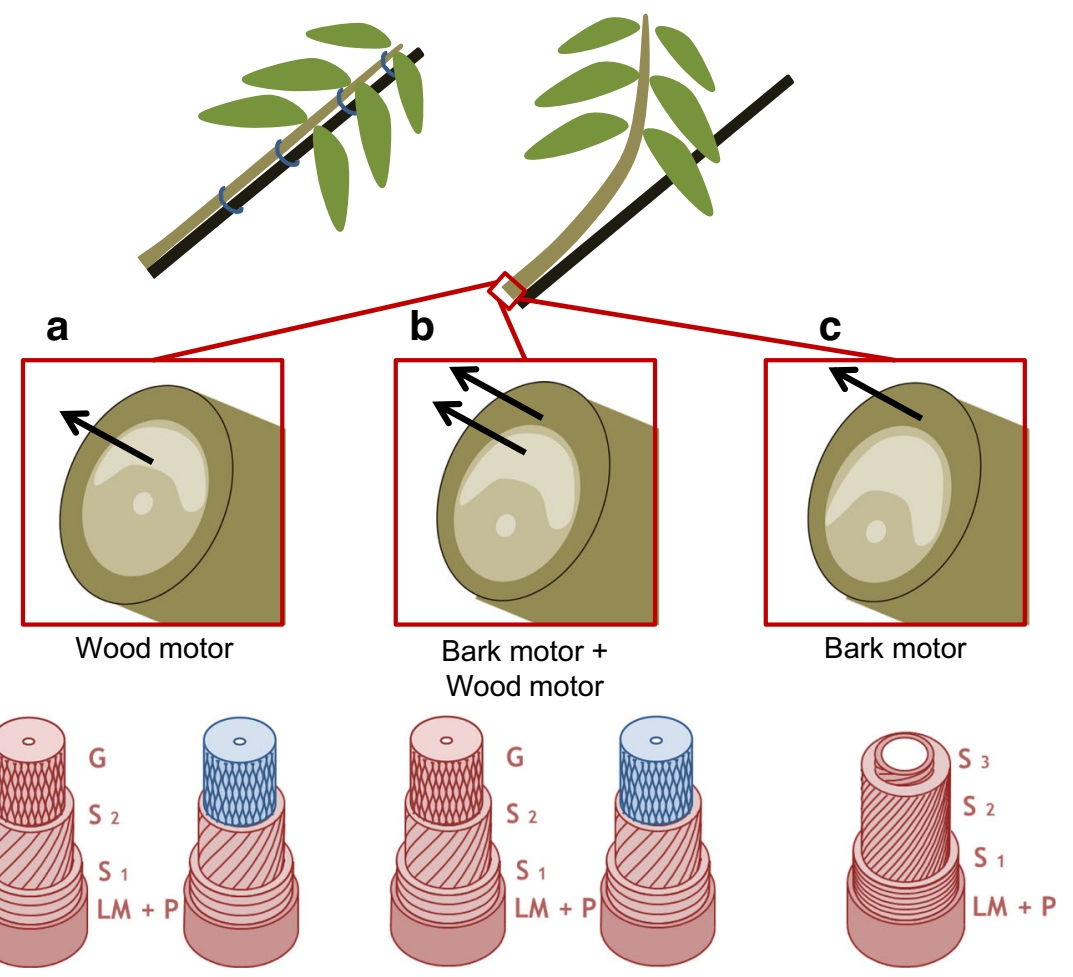

eccentric growth, increasing the amount of forces on one side of the stem (Alméras et al. 2005). This asymmetric production of tensile forces in a stem section generates a bending moment that tends to curve it up, in order to maintain or restore optimal orientation of the woody axes.

Basically, the result of the production of tension wood is a change in stem curvature. It has been shown that this change in curvature depends at first order on the diameter of the stem and the amount of diameter growth (Alméras and Fournier 2009). In order to compare stems of different species, with different size and growth rate, this change in curvature has to be standardized. The concept of gravitropic efficiency, as proposed in Alméras et al. (2009), enables such standardization, based on a biomechanical analysis of size effects (Alméras and Fournier 2009). Stem gravitropic efficiency (Fig. 2) quantifies the ability to generate a movement in a stem of a given size, for a given investment in biomass (i.e. for a given growth increment). The gravitropic efficiency results from all factors that contribute to the up-righting process, i.e. the mechanical stress in bark, the mechanical stress in wood, the amount of tension wood (through the extension of the tension wood arc) and eccentric growth. The effect of these different factors can be distinguished by defining parameters characterizing the action of bark and tension wood independently. Bark action can be deduced from the change in curvature that occurs during debarking of a stem segment, after standardization by stem diameter (Clair et al. 2019; Fig. 2). Tension wood action can be quantified by its maturation strain, that can be computed from the change in curvature that occurs during stem up-righting (Alméras et al. 2018; Fig. 2). It enables comparison of the quality of tension woods, independently of geometric factors (eccentricity and extension of the tension wood arc) affecting the stem gravitropic efficiency.

In previous studies estimating the stem gravitropic efficiency (Coutand et al. 2007; Alméras et al. 2009), the analysis of curvature and computation of the efficiency was performed on trees tilted and let free to up-right. Here we used a different methodology, where the stems are tied to a stake in tilted position, grown in that position and released from the stake at the end of the experiment. With this method, the stimulus (inclination) is maintained maximal, uniform along the stem and constant during the experiment. The release from the stake induces an instantaneous change in curvature. The dependence between curvature, efficiency, diameter and diameter growth in this case differs from the case of free up-righting, and adapted models are necessary (Alméras et al. 2018).

In tension wood studies, poplar has been used as a model species (Pilate et al. 2004b). Tension wood in poplar is characterized by the presence of a gelatinous layer replacing part (or the whole) of the $\mathrm{S}_{2}$ layer of wood fibres (Fig. 1). This gelatinous layer is composed of highly crystalline cellulose oriented along the axis of the fibre, embedded in a matrix of polysaccharides and proteins (Gorshkova et al. 2015; Guedes et al. 2017) with little or no amounts of lignin (Pilate et al. 2004a). When screening a diversity of species, tension wood was first thought to be either with or without G-layers (Onaka 1949; Fisher and Stevenson 1981; Clair et al. 2006). In the meantime, in Simarouba amara Aubl., a species previously 


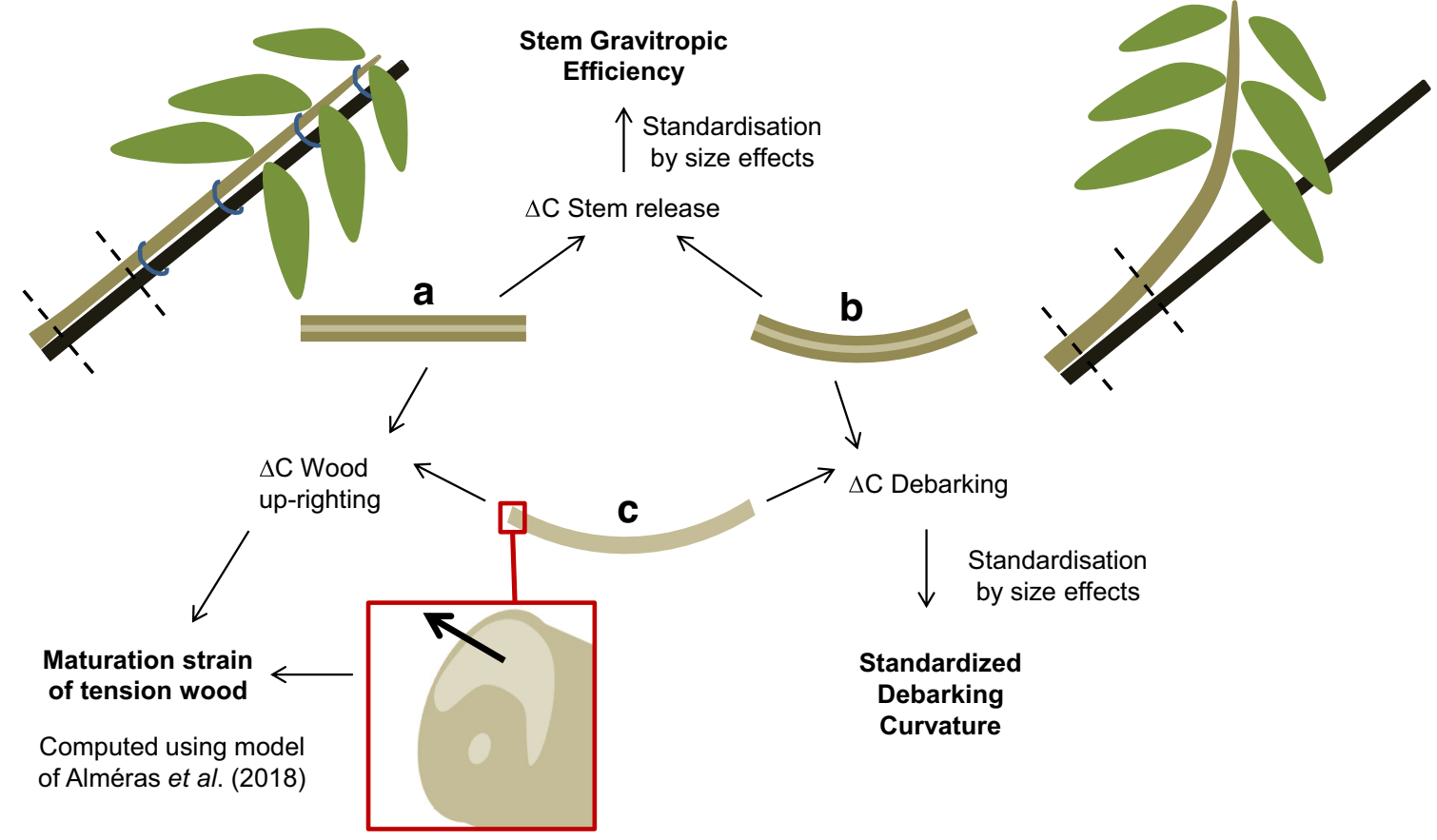

Fig. 2 Schematic representation of the three steps of the experiment: before release of the stem from the stake (a), after release (b), and after debarking (c). $\Delta C$ is the change in curvature computed between two steps of the experiment. The 3 studied parameters (stem gravitropic efficiency,

standardized debarking curvature and maturation strain of tension wood) derive from changes in curvature and morphological characteristics of the section

classified as "without G-layer" (Ruelle et al. 2007b), it was observed that the G-layer is visible in early stages of cell wall maturation, but is later lignified and therefore masked (Roussel and Clair 2015). Most species previously classified as "without G-layer" may have a G-layer masked by lignification (Ghislain and Clair 2017). Consequently, tension wood anatomy is finally defined as displaying a G-layer, with or without lignin, or no G-layer at all (Ghislain and Clair 2017).

Concerning the mechanism setting tension in the G-layer, it was shown with poplar that a strong tensile stress is generated in the cellulose microfibrils during the cell wall maturation process (Clair et al. 2011). Various models have been proposed to explain how the formation of the secondary cell wall generates mechanical stress (Gorshkova et al. 2015; Alméras and Clair 2016). Because the unlignified G-layer was taken as a model, none of the models developed for the G-layer considers the possible implication of lignin in generating mechanical stress. Yet, lignin is considered to have a role in the generation of maturation stress for normal and compression wood. The so-called unified hypothesis (Okuyama et al. 1994; Yamamoto 1998) currently explaining the relations between variations in maturation stress and microfibril angle assumes that lignin incorporation adds compressive stress to the cell wall matrix. In the case of lignified G-layers, this additional compressive stress would tend to reduce the tensile stress generated during the maturation process. On the other hand, a recent model of stress generation in the G-layer
(Alméras and Clair 2016) assumes that tensile stress is generated in the direction of the cell axis due to the interaction between the swelling of the matrix and a connected microfibril network. It assumes that the polysaccharide matrix swells and pushes laterally on the cellulose microfibril network, thus creating a strong tensile stress in the direction of microfibrils. If this mechanism is assumed, the incorporation of lignin to the matrix may generate more matrix swelling and therefore more tension in the cellulose network, leading to an increased tensile stress.

In the case of tension wood without G-layer, it was shown that its action relies on a mechanism primarily based on the interaction between wood and bark (Clair et al. 2019). Phloem fibres are organized as a network in which enlarged parenchyma cells are nested (Böhlmann 1971; Fisher and Mueller 1983; Zajączkowska and Kozakiewicz 2016; Angyalossy et al. 2016). The mechanism implies a radial eccentric growth of wood, pulling tangentially the bark due to expanding circumference which will be redirected into longitudinal stress on the eccentric side thanks to the organization of the fibres network. This mechanism is accompanied by a specific anatomy of reaction wood. The primary action of wood in these species is then to push radially on the bark. A direct action of wood might be added, if this wood is also put under tension during its maturation process, as was shown for two species on which direct measurement of residual strains has been performed on adult trees (Clair et al. 2019). The question arises of 
whether these species are able to cumulate strong tensile stress in both wood and bark to improve their gravitropic efficiency, or whether there is a compromise between these two motors.

Our main questions are as follows: (i) is one anatomy of tension wood (with unlignified G-layer, with lignified G-layer and with no G-layer) leading to a larger gravitropic efficiency, (ii) does lignin affect the tensile stress generation in G-layers and (iii) can the association of wood and bark motors lead to an improved stem gravitropic efficiency?

The method of Alméras et al. (2018) is used here to compare the stem gravitropic efficiency, the maturation strain of tension wood and standardized debarking curvature (Fig. 2) on seedlings of a diversity of species representing the three above-mentioned types of tension wood: with unlignified Glayer, with lignified G-layer and with no G-layer.

\section{Material and methods}

\subsection{Plant material}

Seeds or young seedlings of 21 tropical tree species (Table 1) were collected in French Guiana and grown in a greenhouse in
Kourou. Most seeds or seedlings were sampled in the tropical forest mainly near the Paracou Research Station (Cirad) or the Saint Elie Research Station (IRD) at the vicinity of Sinnamary. Other species were collected as follows: Tarrietia utilis (Sprague) Sprague seedlings were collected in the plantation plot of the Paracou CIRAD Station, Gossypium hirsutum L. seedlings were collected in a private garden in Kourou. Theobroma grandiflorum (Willd. ex Spreng.) K.Schum. seeds were collected from several fruits bought on the Kourou market, and Hevea guianensis Aubl. and Theobroma cacao L. saplings were provided by the CRB-PPG, CIRAD. After being transplanted in pots and when the stem was at least $25 \mathrm{~cm}$ high, 10 to 15 plants per species were tied to a stake and acclimatized in the experimentation greenhouse for 1 month. The stem was tied to a stake every $20 \mathrm{~cm}$. To avoid stem damage due to stem growth, we regularly slightly loosened the rigid ties.

In February 2016, most stems were tilted at $45^{\circ}$ (see column "Day of tilt" in dataset, Ghislain et al. 2019). Ties were added throughout the experiment to maintain the apex at $45^{\circ}$. Eventual sprouts were cut during the whole experiment, to ensure that the main stem continues reacting and producing tension wood. Sprout production was mainly observed in

Table 1 List of species grown for the study

\begin{tabular}{|c|c|c|c|c|c|c|}
\hline Family & Species & Code & Stem diam. & $N_{\text {stem \& morphology }}$ & $N_{\text {debark \& TW }}$ & Anat. group \\
\hline Urticaceae & Cecropia palmata Willd. & Cpa & 11.2 & 9 & 9 & Unlignified G-layer \\
\hline Euphorbiaceae & Hevea guianensis Aubl. & $\mathrm{Hg}$ & 13.5 & 9 & 9 & Unlignified G-layer \\
\hline Fabaceae & Macrolobium bifolium (Aubl.) Pers. & Mbf & 10.6 & 10 & 10 & Unlignified G-layer \\
\hline Burseraceae & Protium heptaphyllum (Aubl.) Marchand & $\mathrm{Ph}$ & 7.6 & 9 & 9 & Unlignified G-layer \\
\hline Burseraceae & Protium opacum Swart & Po & 6.8 & 9 & 4 & Unlignified G-layer \\
\hline Simaroubaceae & Simarouba amara Aubl. & $\mathrm{Sa}$ & 7.0 & 10 & 10 & Unlignified G-layer \\
\hline Moraceae & Bagassa guianensis Aubl. & $\mathrm{Bg}$ & 5.5 & 13 & 9 & Lignified G-layer \\
\hline Fabaceae & Eperua grandiflora (Aubl.) Benth. & $\mathrm{Eg}$ & 7.8 & 9 & 9 & Lignified G-layer \\
\hline Meliaceae & Guarea Guidonia (L.) Sleumer & Ggu & 7.6 & 10 & 9 & Lignified G-layer \\
\hline Chrysobalanaceae & Licania macrophylla Benth. & $\mathrm{Lm}$ & 8.4 & 10 & 10 & Lignified G-layer \\
\hline Lecythidaceae & Lecythis persistens Sagot & Lpe & 7.2 & 10 & 10 & Lignified G-layer \\
\hline Salicaceae & Laetia procera (Poepp.) Eichler & Lp & 7.1 & 10 & 10 & Lignified G-layer \\
\hline Sapotaceae & Manilkara bidentata (A.DC.) A.Chev. & Mbd & 7.1 & 11 & 11 & Lignified G-layer \\
\hline Lauraceae & Sextonia rubra (Mez) Van der Werff & $\mathrm{Sr}$ & 7.3 & 10 & 10 & Lignified G-layer \\
\hline Boraginaceae & Cordia alliodora (Ruiz \& Pav.) Oken & $\mathrm{Ca}$ & 10.8 & 8 & 8 & No G-layer \\
\hline Malvaceae & Gossypium hirsutum L. & Gh & 6.3 & 11 & 11 & No G-layer \\
\hline Malvaceae & Pachira aquatica Aubl. & $\mathrm{Pa}$ & 9.2 & 11 & 11 & No G-layer \\
\hline Malvaceae & Theobroma cacao L. & $\mathrm{Tc}$ & 11.6 & 11 & 11 & No G-layer \\
\hline Malvaceae & Theobroma grandiflorum (Willd. ex Spreng.) K.Schum. & $\mathrm{Tg}$ & 7.4 & 15 & 9 & No G-layer \\
\hline Malvaceae & Tarrietia utilis (Sprague) Sprague & $\mathrm{Tu}$ & 7.7 & 10 & 10 & No G-layer \\
\hline Myristicaceae & Virola michelii Heckel & $\mathrm{Vm}$ & 5.8 & 8 & 8 & No G-layer \\
\hline
\end{tabular}

Stem diam., mean final diameter of the stems $(\mathrm{mm}) ; N_{\text {stem \& morphology }}$ number of trees per species for stem gravitropic efficiency and morphological measurements; $N_{\text {debark \& } T \text { W }}$ number of trees per species for measurements of standardized debarking curvature and maturation strain of tension wood; Anat. group, anatomical group of the species based on their tension wood anatomy 
Virola michelii Heckel, Cordia alliodora (Ruiz \& Pav.) Oken, Lecythis persistens Sagot and Theobroma grandiflorum.

The trees that did not grow or died during the experiment were removed from the study. The number of trees per species is indicated in Table 1. Trees were processed when their diameter had increased by at least $50 \%$. Depending on their growth rate, trees were kept tilted for 47 to 315 days (see column "Time of tilting" in dataset, Ghislain et al. 2019). Final mean stem basal diameter ranges between 5.8 and 13.5 $\mathrm{mm}$.

\subsection{Curvature measurements}

The change in curvature following the release of the stake, and that following the removing of the bark, was measured using the same procedure as in Clair et al. (2019). A first photograph of the stem was taken to evaluate the initial curvature of a 20$\mathrm{cm}$-long basal segment of the stem. The curvature was computed as the change in angle along the segment, divided by its length (Fig. 3), and is expressed in $\mathrm{dm}^{-1}$. Then, the stem was released from the stake, the basal segment was cut, laid on the floor to cancel any effect of self-weight, and a second photograph was immediately taken to evaluate the curvature after release. The change in curvature of the stem $\left(\Delta C_{\mathrm{S}}\right)$ due to the release of the stake was computed as the difference between the curvatures measured on the first and second photographs. Then, the bark (including all tissues located outside the vascular cambium) was removed on a central 5-cm-long portion of the stem segment, a third photograph was taken, and the curvature of the 5-cm-long portion was measured. Debarking was done immediately after the second photograph to avoid any possible effect of drying. The change in curvature due to debarking $\left(\Delta C_{\mathrm{B}}\right)$ was computed as the difference between the curvatures measured on the second and the third photographs. A negative value of $\Delta C_{\mathrm{B}}$ indicates that the stem is less curved after removing the bark. This means that the bark was actively contributing to the tree up-righting. Conversely, a positive

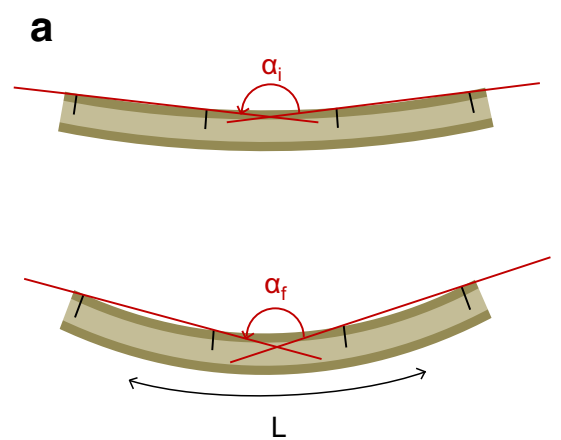

Fig. 3 Schematic representation of measurements of the change in curvature after the release of the stake (a) and after removing the bark (b). $\alpha$ is the angle between two lines drawn thanks to fixed marks drawn on the stem. $L$ is the length and goes from the middle of the two marks on value of $\Delta C_{\mathrm{B}}$ indicates that the bark was partly impeding stem up-righting.

The change in curvature of the wood segment is deduced as: $\Delta C_{\mathrm{W}}=\Delta C_{\mathrm{S}}+\Delta C_{\mathrm{B}}$.

\subsection{Stem anatomy and morphological measurements}

A $20-50-\mu m$-thick cross section of the whole stem near the debarked area was cut with a sliding microtome and stained with safranin and Astra blue (Jourez et al. 2001). This stains the unlignified G-layer in blue and the lignified G-layer in red. Species were classified in three anatomical groups following the presence/absence of G-layer and the main trend in G-layer lignification: unlignified G-layers, lignified G-layers or no Glayer (Fig. 4). In addition, Hevea guianensis and Laetia procera (Poepp.) Eichler have multi-layered G-layers respectively made of two or multiple sub-layers. As the aim of this experiment was to characterize the maturation strain of different anatomies of tension wood, we based our classification on the sections observed in this study.

Tension and opposite bark thicknesses, tension and opposite wood ring thicknesses, angular extension of the tension wood sector and diameters of pith, initial wood and final wood were measured with ImageJ (Fig. 5). In all species except Guarea guidonia (L.) Sleumer, the position corresponding to the date of tilting was easily detected on stem sections thanks to the change in morphology: growth eccentricity, change in fibre cell wall thickness and change in the stain of the fibre cell wall. For Guarea guidonia, the rings at the tilting date were less marked on opposite wood. Position at the tilting date was therefore calculated from position at the day of tilting determined on tension side with hypothesis of circularity of the stem before tilting. Together with curvature measurements, these morphological measurements are used to calculate the stem gravitropic efficiency and the maturation strain of tension wood to compare gravitropic reactions of the trees.
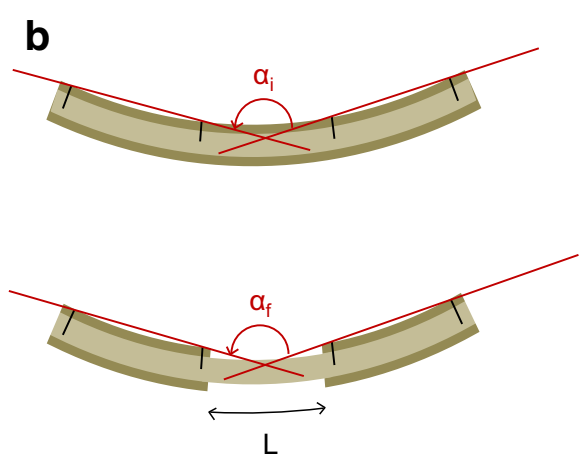

left side to the middle of the two marks on right side (a) or is the length of the segment where bark was removed. The change in curvature is related to the change of $\alpha$ and the length $L: \Delta C=\left(\alpha_{\mathrm{f}}-\alpha_{\mathrm{i}}\right) / L$ 

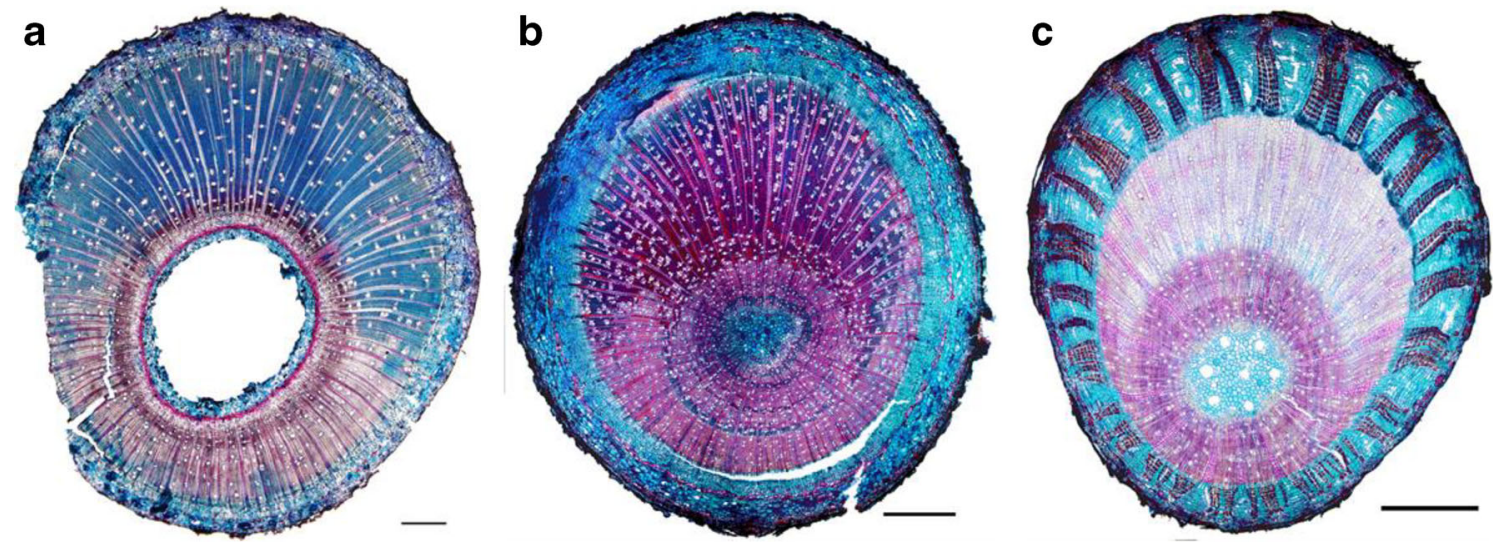

Fig. 4 Anatomical groups of tension wood defined for this study. Unlignified G-layer stained in blue in Cecropia palmata (a), lignified G-layer stained in red in Sextonia rubra (b) and No G-layer in Theobroma grandiflorum. Scale bar $=1 \mathrm{~mm}$

The eccentricity of diameter growth was quantified for wood and bark as (abbreviations of parameters are detailed in the legend of the Fig. 5):

Wood ecc $=\frac{T_{\mathrm{TW}}-T_{\mathrm{OW}}}{T_{\mathrm{TW}}+T_{\mathrm{OW}}}$

Bark ecc $=\frac{T_{\mathrm{TB}}-T_{\mathrm{OB}}}{T_{\mathrm{TB}}+T_{\mathrm{OB}}}$

Eccentricity has no units and ranges between -1 and 1 . It is zero when growth is concentric, positive when more wood or bark is produced on the tension side, and reaches 1 if the thickness of the wood or bark ring is reduced to 0 on the lower side.

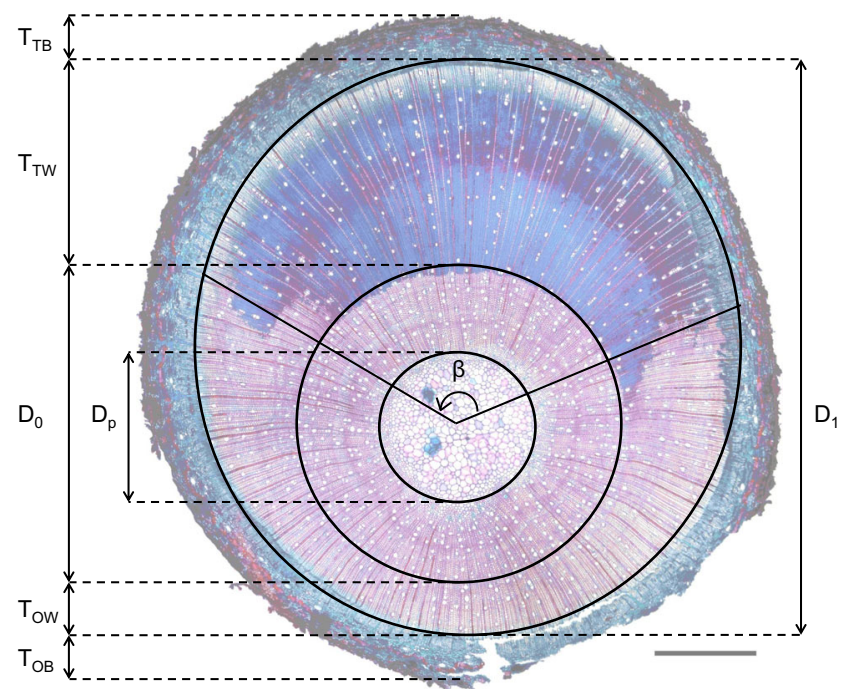

Fig. 5 Illustration of the parameters describing section's morphology. $D_{0}$, initial wood diameter; $D_{1}$, final wood diameter; $D_{\mathrm{p}}$, pith diameter; $T_{T W}$, tension wood ring thickness; $T_{O W}$, opposite wood ring thickness; $T_{T B}$, tension bark thickness; $T_{O B}$, opposite bark thickness; $\beta$, angular extension of tension wood (Protium opacum stained with SafraninAstra blue, scale bar $=1 \mathrm{~mm}$ )

\subsection{Computation of stem gravitropic efficiency}

The computation of stem gravitropic efficiency is based on the analysis of size effects for the change in curvature of a stem maintained tilted (Alméras et al. 2018). The underlying model considers a theoretical stem section maintained tilted and submitted to a growth increment with heterogeneous maturation strains. The section is assumed homogeneous and concentric, with sine variations in maturation strain (Alméras et al. 2018). The change in curvature that occurs when releasing the stem from the stake can be expressed as a function of the diameter at the beginning $\left(D_{\mathrm{i}}\right)$ and at the end $\left(D_{\mathrm{f}}\right)$ of the experiment, and the maximal maturation strain in the section. Stem gravitropic efficiency is equal to this theoretical maximal maturation strain, and will be expressed in $\mu$ strains (microstrains or $\left.10^{-6} \mathrm{~m} \cdot \mathrm{m}^{-1}\right)$.

Stem Gravitropic Efficiency $=-\frac{3}{4} \Delta C_{\mathrm{S}} \frac{D_{\mathrm{f}}^{4}}{D_{\mathrm{f}}^{3}-D_{\mathrm{i}}^{3}}$

The curvature of the whole stem $\left(\Delta C_{\mathrm{S}}\right)$ is here used to calculate the stem gravitropic efficiency. It represents the ability of the whole stem to upright using both wood and bark. A stem able to upright has a positive curvature of the whole stem $\left(\Delta C_{\mathrm{S}}>0\right)$ and will therefore have a negative value of stem gravitropic efficiency (corresponding to a tensile maturation strain).

\subsection{Computation of standardized debarking curvature}

The curvature is defined at the level of a segment as the change in angle per unit length. However, the change in curvature in response to stress induced in the stem tissues strongly depends on the diameter of the stem. To remove this size effect, we use a standardized curvature, defined as in Clair et al. (2019): 
Standardized Debarking Curvature $=\Delta C_{\mathrm{B}} \frac{D}{D_{\text {ref }}}$

where $D$ is the stem diameter and $D_{\text {ref }}$ is a reference diameter arbitrarily fixed at $D_{\text {ref }}=1 \mathrm{~cm}$. Standardized debarking curvature is homogeneous to a curvature and will be expressed in ${ }^{\circ} \mathrm{dm}^{-1}$ (Clair et al. 2019).

To assess bark contribution to up-righting, the difference with a theoretical null mean is tested for each species. A significant positive value indicates that bark impedes stem uprighting, a significant negative value means that bark is contributing to up-righting. A null value indicates that bark is sufficiently strained to follow the up-righting movement generated by wood.

\subsection{Computation of the maturation strain of tension wood}

The maturation strain of tension wood is computed from the change in curvature of wood only $\left(\Delta C_{\mathrm{W}}\right)$ using the model with step variation of material properties of Alméras et al. (2018). It was computed numerically using Microsoft Excel and Visual Basic. The maturation strain of tension wood is expressed in $\mu$ strains (microstrains or $10^{-6} \mathrm{~m} \cdot \mathrm{m}^{-1}$ ). It is generally negative, and a more negative value indicates a higher tensile stress in tension wood. The strain of normal wood was considered to be $-500 \mu$ strains. Indeed, mean strain of normal wood of adult trees of previous studied trees was estimated at - $723 \mu$ strains (Clair et al. 2006) and - $397 \mu$ strains (Clair et al. 2019). This variability being 1 order of magnitude lower than the variability of the maturation strain of tension wood, using a mean value of $-500 \mu$ strains for normal wood has negligible influence on the results.

To assess wood contribution to up-righting, the difference with this theoretical mean value of normal wood is tested for each species. A significant difference indicates that wood actively contributes to stem up-righting.

In this model, wood growth is considered eccentric and tension wood is characterized by its angular extension $(\beta)$ and its mechanical properties compared to normal wood. The ratio of elastic modulus between tension wood and normal wood of tropical species typically varies between 0.8 and 1.5 (Alméras et al. 2005; Ruelle et al. 2007a). In this study it is considered to be 1 , on account of the weak variation of the curvature for a ratio between 0.8 and 1.5 (Alméras et al. 2018).

\subsection{Statistical analyses}

Statistical analyses were performed using R ( $\mathrm{R}$ Core Team 2016). Individual trees were taken as statistical units. Homogeneity of the variance of studied parameters was checked with package lawstat and either parametric of nonparametric tests were performed accordingly. Analysis of variance of species effects was performed using ANOVA or a Kruskall-Wallis test with package stats. Either Tukey test or Dunn test was used to perform multiple pairwise comparison. Student's $t$ test was performed with package stats to test the difference for each species with a theoretical mean of 0 for all parameters except the maturation strain of tension wood for which theoretical value is set as $-500 \mu$ strains. To compare the effect of the anatomical group on the variables, a nested ANOVA was performed with species nested as a random effect. Package lsmeans was used to perform multiple pairwise comparison.

\section{Results}

\subsection{Stem gravitropic efficiency}

In all trees, stem growth generated mechanical stress in the tissues that induced an instantaneous upward change in curvature when releasing the stem from the stake. As a consequence, all measured values of stem gravitropic efficiency are negative. Analysis of variance revealed significant differences between species $(P<0.001$; Fig. 6$)$. The mean value of stem gravitropic efficiency per species ranged between $-30,424$ $\mu$ strains for Lecythis persistens and $-6786 \mu$ strains for Guarea guidonia (Table 2) for an overall mean of - 16989 $\mu$ strains. Highest magnitude of stem gravitropic efficiency is achieved by Cecropia palmata Willd., Macrolobium bifolium (Aubl.) Pers., Eperua grandiflora (Aubl.) Benth., Lecythis persistens, Laetia procera and Theobroma grandiflorum. Lowest magnitudes are observed on Hevea guianensis, Protium heptaphyllum (Aubl.) Marchand, Guarea guidonia, Licania macrophylla Benth. and Cordia alliodora (Fig. 3). The nested analysis of variance did not reveal any significant effect of the anatomical groups on stem gravitropic efficiency $(P>0.05$; Fig. 7).

\subsection{Standardized debarking curvature}

The sign of the change in curvature during debarking varied between species, being either negative, close to zero or positive. Mean value of standardized debarking curvature per species varied from $-7.0^{\circ} \mathrm{dm}^{-1}$ (Pachira aquatica Aubl.) to + $1.9^{\circ} \mathrm{dm}^{-1}$ (Macrolobium bifolium). Bark significantly impeded wood up-righting for Cecropia palmata, Macrolobium bifolium, Bagassa guianensis Aubl., Lecythis persistens, Laetia procera, Manilkara bidentata (A.DC.) A.Chev. and Sextonia rubra (Mez) van der Werff (Table 2). Bark significantly contributed to up-righting for Cordia alliodora, Gossypium hirsutum, Pachira aquatica, Theobroma cacao, Theobroma grandiflorum and Tarrietia utilis. For the other species, bark was not significantly impeding nor improving 


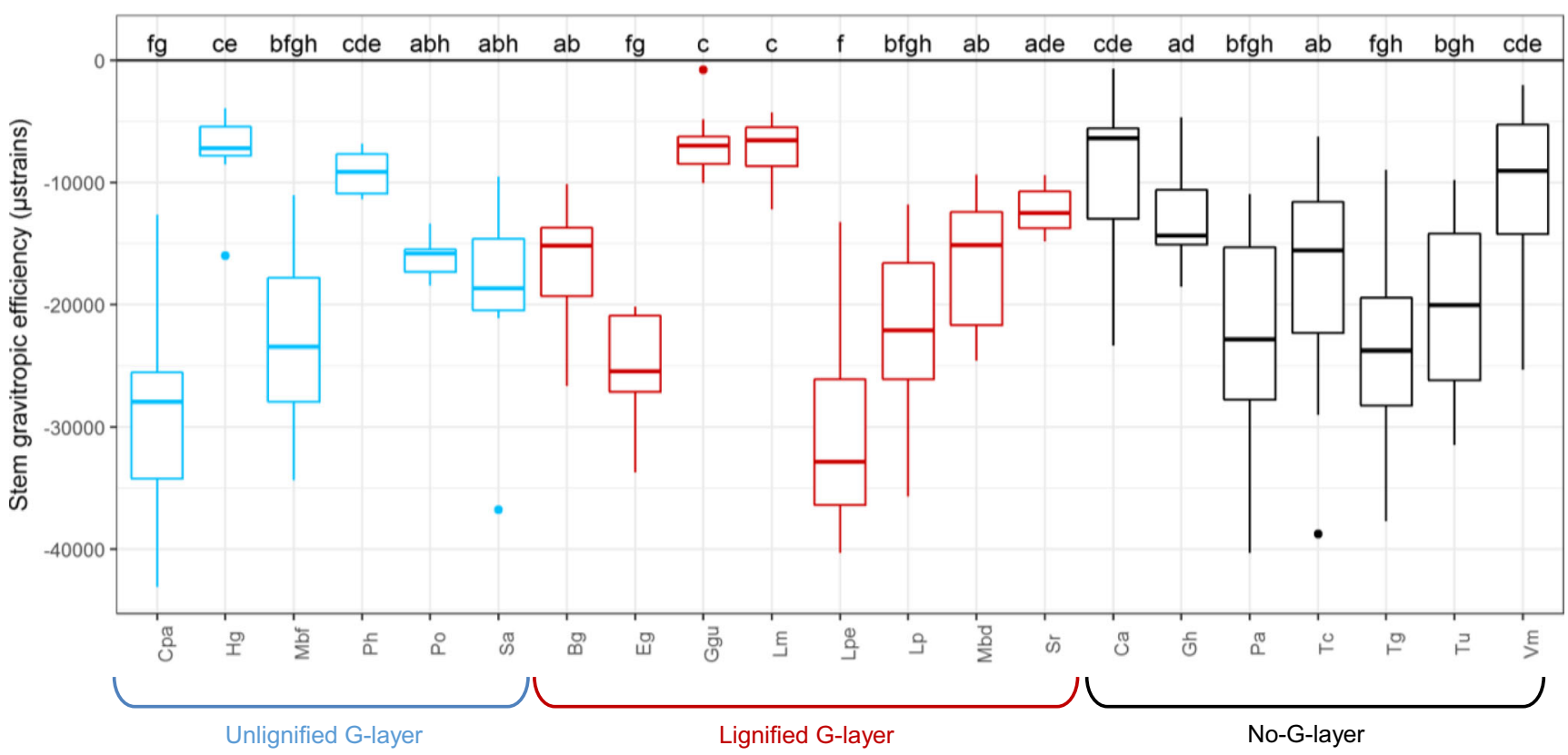

Fig. 6 Inter-specific comparison of stem gravitropic efficiency. The boxplots represent the median value (horizontal bar), the 75th and 25th percentiles (upper and lower hinge), and highest/lowest value not exceeding $1.5 \times$ distance between 25 th and 75 th percentiles from upper/

wood up-righting, i.e. bark and tension wood were both contributing to up-righting.

Nested analysis of variance revealed a significant effect of the anatomical group on standardized debarking curvature $(P$ $<0.001)$. Post-hoc analysis indicated a significant difference between the group without G-layer and groups with G-layer (Fig. 7). Species with no G-layer clearly have a significantly more negative standardized debarking curvature $\left(-4.0^{\circ} \mathrm{dm}^{-1}\right)$ and have thereby a stronger contribution of their bark to the up-righting process. In species with G-layer, standardized debarking curvature is generally positive, meaning that bark impedes the up-righting movement.

\subsection{Maturation strain of tension wood}

Analysis of variance revealed significant between-species differences in the maturation strain of tension wood. Mean value ranged between - 13,983 $\mu$ strains (Cecropia palmata) and $768 \mu$ strains (Pachira aquatica) for an overall mean of -6113 ustrains.

For Pachira aquatica, Theobroma cacao and Theobroma grandiflorum, difference in maturation strain between normal and tension wood was not significant (Table 2). All other species generate significantly more tensile stress in tension wood than in normal wood. Among G-layers species, Laetia procera does not seem to have stronger or lower maturation strain due to multi-layered G-layers in its tension wood.

The anatomical group had a significant effect on the values of maturation strain of tension wood $(P<0.01$; Fig. 7). There lower hinge (whiskers). Result of Dunn test is indicated above boxplots, same letters indicate no significant difference of stem gravitropic efficiency between species. Abbreviations of species names are indicated as in Table 1

is no significant difference between unlignified and lignified G-layers. On the other hand, the anatomical group "no Glayer" displayed a lower magnitude of the maturation strain of tension wood (-2091 $\mu$ strains) than the "G-layer" anatomical groups (-8112 strains).

\subsection{Wood and bark eccentricity}

For all trees, wood eccentricity was positive, i.e. all trees produced more wood on the tension side (Table 2). The mean value per species varied between 0.33 and 0.94 , with a global mean of 0.75 . This high eccentricity may be exacerbated by the solicitation: maintained tilted at $45^{\circ}$ all along the experiment, trees were strongly reacting without reaching the vertical. There was a significant difference between species $(P<$ $0.001)$, and between anatomical groups $(P<0.05$; Fig. 7). Wood eccentricity of unlignified G-layer was not different from lignified G-layer. Wood eccentricity was significantly higher in the anatomical group "No G-layer" $(0.85)$ than in the anatomical groups with G-layers (0.64).

There were significant differences in bark eccentricity between species and the mean value per species varies between -0.07 and 0.37 . None of the species have a significantly thicker bark on the opposite side. Many species have a significantly thicker bark on the tension side: Hevea guianensis, Macrolobium bifolium, Simarouba amara, Bagassa guianensis, Lecythis persistens, Cordia alliodora, Gossypium hirsutum, Pachira aquatica, Theobroma cacao, Theobroma grandiflorum, Tarrietia utilis and Virola michelii. 
Table 2 Mean value per species of stem gravitropic efficiency (Stem grav. eff.), standardized debarking curvature (Stand. debark. curv.), maturation strain of tension wood (TW mat. strain), wood eccentricity index (Wood ecc.) and bark eccentricity (Bark ecc.)

\begin{tabular}{|c|c|c|c|c|c|}
\hline $\begin{array}{l}\text { Species } \\
\text { Units }\end{array}$ & $\begin{array}{l}\text { Stem grav. eff. } \\
\text { ( } \mu \text { strains) }\end{array}$ & $\begin{array}{l}\text { Stand. debark. curv. } \\
\left({ }^{\circ} \mathrm{dm}^{-1}\right)\end{array}$ & $\begin{array}{l}\text { TW mat. strain } \\
\text { ( } \mu \text { strains) }\end{array}$ & $\begin{array}{l}\text { Wood ecc. } \\
(-)\end{array}$ & $\begin{array}{l}\text { Bark ecc. } \\
(-)\end{array}$ \\
\hline Cecropia palmata & $-28,831^{* * * *}$ & $1.9^{* *}$ & $-13,983^{* * * *}$ & $0.61^{* * * *}$ & $0.04^{\mathrm{NS}}$ \\
\hline Hevea guianensis & $-7455^{* * * *}$ & $-0.3^{\mathrm{NS}}$ & $-3169^{* *}$ & $0.69^{* * * *}$ & $0.14^{*}$ \\
\hline Macrolobium bifolium & $-22,841^{* * *}$ & $1.9^{* * * *}$ & $-13,516^{* * *}$ & $0.44^{* * * *}$ & $0.14^{* *}$ \\
\hline Protium heptaphyllum & $-9184^{* * *}$ & $0.8^{\mathrm{NS}}$ & $-5715^{* * *}$ & $0.48^{* * * *}$ & $-0.07^{\mathrm{NS}}$ \\
\hline Protium opacum & $-16,004^{* * * *}$ & $0.8^{\mathrm{NS}}$ & $-7567^{* * * *}$ & $0.67^{* * *}$ & $0.01^{\mathrm{NS}}$ \\
\hline Simarouba amara & $-18,496^{* * * *}$ & $0.2^{\mathrm{NS}}$ & $-10,961^{* * * *}$ & $0.93^{* * * *}$ & $0.17^{* *}$ \\
\hline Bagassa guianensis & $-16,158^{* * * *}$ & $1.7^{* * * *}$ & $-9198^{* * * *}$ & $0.57^{* * * *}$ & $0.20^{* * *}$ \\
\hline Eperua grandiflora & $-25,051^{* * * *}$ & $1.0^{\mathrm{NS}}$ & $-11,105^{* * *}$ & $0.66^{* * *}$ & $0.04^{\mathrm{NS}}$ \\
\hline Guarea guidonia & $-6786^{* * * *}$ & $0.7^{\mathrm{NS}}$ & $-3886^{* * *}$ & $0.33^{* * * *}$ & $0.00^{\mathrm{NS}}$ \\
\hline Licania macrophylla & $-7143^{* * * *}$ & $-0.1^{\mathrm{NS}}$ & $-2853^{* * * *}$ & $0.73^{* * * *}$ & $0.08^{\mathrm{NS}}$ \\
\hline Lecythis persistens & $-30,424^{* * *}$ & $1.0^{*}$ & $-11,859^{* * *}$ & $0.85^{* * *}$ & $0.13^{*}$ \\
\hline Laetia procera & $-21,773^{* * * *}$ & $1.0^{* * * *}$ & $-8979^{* * * *}$ & $0.78^{* * * *}$ & $-0.01^{\mathrm{NS}}$ \\
\hline Manilkara bidentata & $-17,065^{* * *}$ & $1.2^{* * * *}$ & $-5474^{* * *}$ & $0.68^{* * * *}$ & $0.02^{\mathrm{NS}}$ \\
\hline Sextonia rubra & $-12,310^{* * *}$ & $0.3^{* *}$ & $-5080^{* * *}$ & $0.55^{* * *}$ & $0.02^{\mathrm{NS}}$ \\
\hline Cordia alliodora & $-9766^{*}$ & $-0.9^{* * *}$ & $-2445^{*}$ & $0.94^{* * * *}$ & $0.21^{* * * *}$ \\
\hline Gossypium hirsutum & $-13,037^{* * * *}$ & $-3.2^{* * * *}$ & $-2219^{*}$ & $0.84^{* * * *}$ & $0.30^{* * * *}$ \\
\hline Pachira aquatica & $-22,939^{* * *}$ & $-7.0^{* * * *}$ & $-768^{\mathrm{NS}}$ & $0.93^{* * *}$ & $0.19^{* * * *}$ \\
\hline Theobroma cacao & $-17,825^{* * *}$ & $-3.8^{* * *}$ & $-1728^{\mathrm{NS}}$ & $0.87^{* * * *}$ & $0.24^{* * * *}$ \\
\hline Theobroma grandiflorum & $-24,042^{* * *}$ & $-6.1^{* * * *}$ & $-2319^{\mathrm{NS}}$ & $0.92^{* * * *}$ & $0.37^{\text {***** }}$ \\
\hline Tarrietia utilis & $-20,285^{* * *}$ & $-5.3^{* * *}$ & $-1870^{*}$ & $0.68^{* * * *}$ & $0.28^{* * * *}$ \\
\hline Virola michelii & $-10,702^{* *}$ & $-0.4^{\mathrm{NS}}$ & $-3896^{* *}$ & $0.68^{* * * *}$ & $0.29^{* * * *}$ \\
\hline
\end{tabular}

Asterisks indicate the difference with a theoretical null mean (Stem grav. eff., Stand. debark. curv., Wood ecc. and Bark ecc.) or with a theoretical mean of -500 (TW mat. strain)

NS not significant

$* P<0.05 ; * * P<0.01 ; * * * P<0.001$

For the other species, no difference was detected between upper and lower bark thickness. The anatomical group "No G-layer" had a significantly higher bark eccentricity $(P<$ 0.001; Fig. 7).

\section{Discussion}

\subsection{Classification in anatomical group}

In most cases, the species could be easily classified based on the most represented type of G-layer. Tension wood lignification is not always a binary trait. In some species, both lignified and non-lignified G-layers can be observed on the same section. For instance, in Protium opacum Swart, most G-layers are not lignified, although a few lignified G-layers are visible (see anatomical section of Fig. 5). This species was classified as having unlignified G-layers. The seedlings of Simarouba amara of this study were sampled before their lignification and are therefore classified as "Unlignified G-layer" whereas it is known that in this species tension wood becomes lately lignified (Roussel and Clair 2015). G-layers of Laetia procera are also lately lignified. Half of the seedlings of this study were sampled after their lignification. This species was classified as "Lignified G-layer".

\subsection{Diversity of gravitropic reactions}

All trees reacted continuously to tilting in response to the stimulus all along the experiment. This experimental design generates a continuously strong reaction, in contrast with trees freely recovering verticality in which tension wood production decreases when the stem comes close to the vertical position (Alméras et al. 2009). The magnitude of stem gravitropic efficiency is therefore expected to be much higher than when measured on un-staked trees. Two species and one genus are in common with the experiment of Alméras et al. (2009). For two species, trees freely recovering from tilting reach indeed a lower magnitude of stem gravitropic efficiency than trees maintained tilted by the stake. Eperua grandiflora and Cecropia obtusa have stem gravitropic efficiency of respectively - 8260 and - $9720 \mu$ strains in Alméras et al. (2009) 

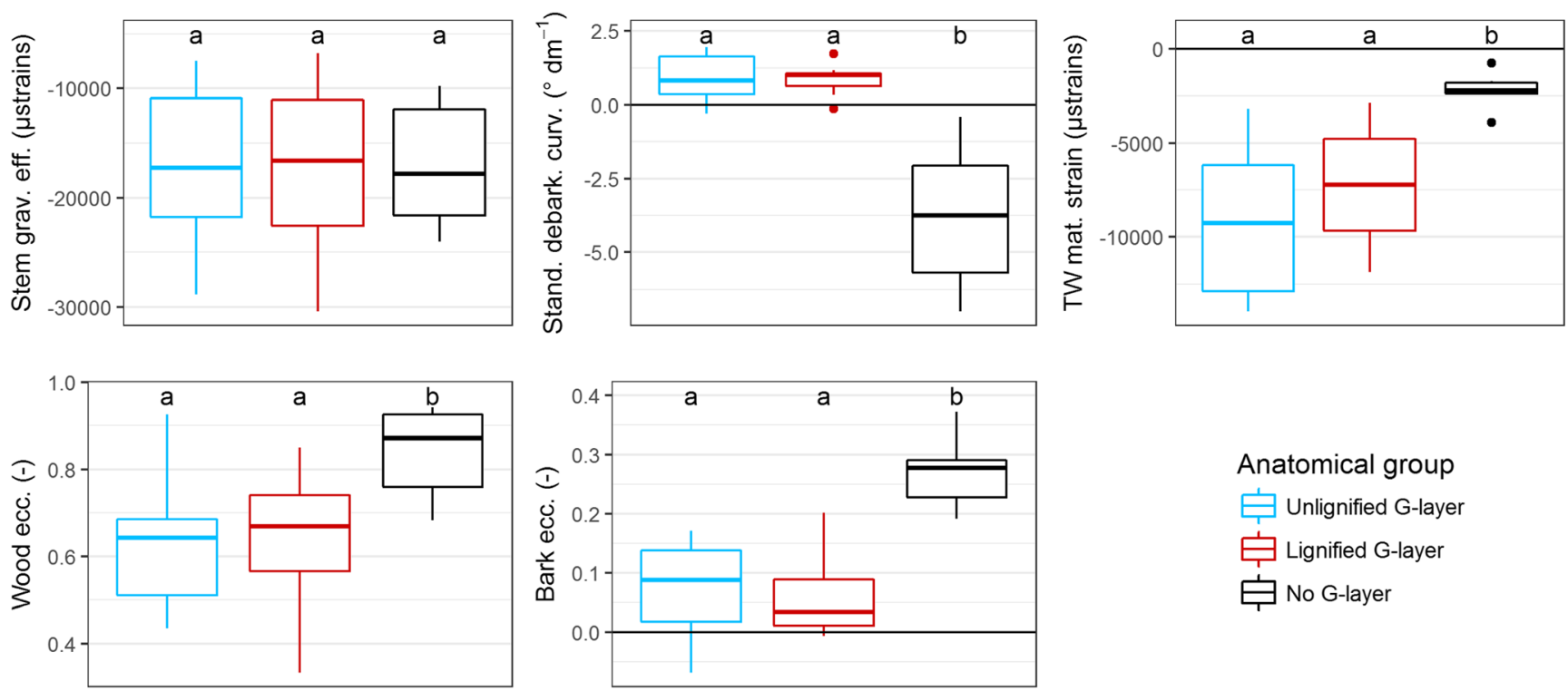

Fig. 7 Comparison between anatomical groups of the stem gravitropic efficiency (Stem grav. eff.), standardized debarking curvature (Stand. debark. curv.), maturation strain of tension wood (TW mat. strain), wood eccentricity (Wood ecc.) and bark eccentricity (Bark ecc.). The boxplots represent the median value (horizontal bar), the 75th and 25th

percentiles (upper and lower hinge), and highest/lowest value not exceeding $1.5 \times$ distance between 25 th and 75 th percentiles from upper/ lower hinge (whiskers). Letters indicate results of post-hoc pairwise comparison test: same letters indicate there is no significant difference between anatomical groups

whereas staked trees of Eperua grandiflora and Cecropia palmata reach values of $-25,051$ and $-28,831 \mu$ strains. Virola michelii has closer values of stem gravitropic efficiency when comparing the free up-righting and the staking methods ( -8160 and $-10,702 \mu$ strains, respectively).

The difference in stem gravitropic efficiency between species within a group was higher than the difference between anatomical groups, which indicates a strong inter-specific variation. No significant difference was recorded between anatomical groups. Therefore, similar levels of stem gravitropic efficiency can be achieved either by strong maturation strains in wood (tension wood with G-layers, lignified or not) or by strong bark action and large wood and bark eccentricity (tension wood without G-layers).

\subsection{No evidence that G-layer lignification contributes to maturation strain}

The main trend in G-layer lignification did not allow to significantly distinguish groups based on their maturation strain of tension wood. In four species, we sampled trees with various levels of lignification. Even at the intra-specific level, no trend was observable between G-layer lignification and the maturation strain of tension wood; trees with more lignified G-layers were not associated to a stronger or weaker maturation strain compared to trees with more unlignified G-layers (Fig. 8).

It seems therefore that lignin in the G-layer does not contribute to additional or reduced generation of maturation stress in tension wood. To be consistent with the model of stress

generation in the G-layer (Alméras and Clair 2016), lignin would therefore be deposited in the G-layer without creating either any swelling of the matrix or any interaction with the cellulose microfibril network. This could be if lignin is deposited inside the mesopores without any change in the pore structure, as suggested by the results of Chang et al. (2015). This hypothesis is supported by the observation of the mesoporous texture in G-layers during the maturation process of Simarouba amara tension wood fibres. Before lignification,

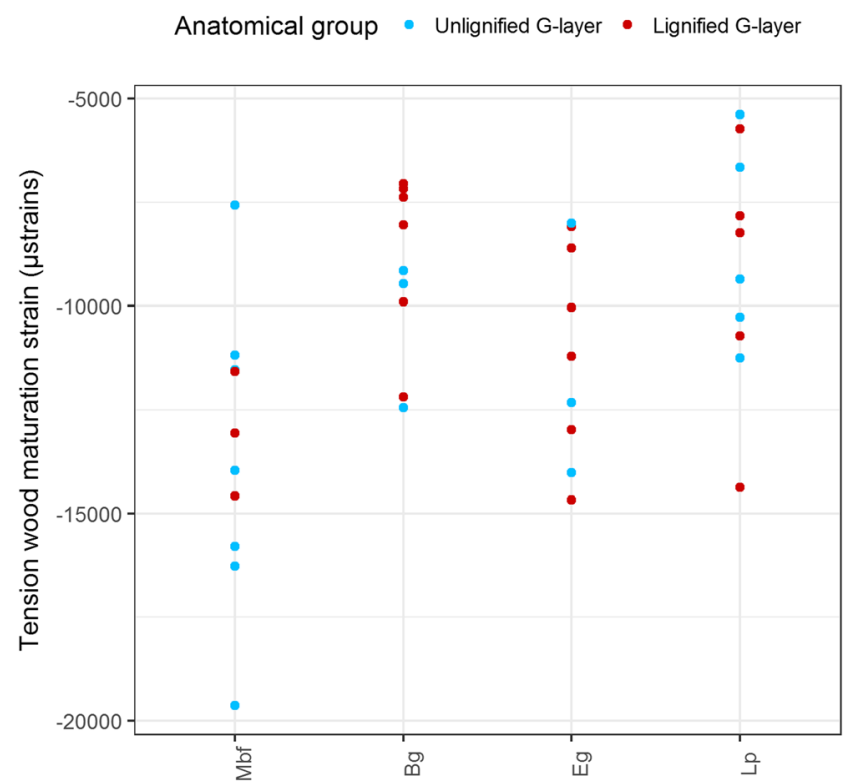

Fig. 8 Tension wood maturation strain of four species (Macrolobium bifolium, Bagassa guianensis, Eperua grandiflora, Laetia procera) with intra-specific variations of the main trend in G-layer lignification 
mesoporosity is similar to mesoporous structure in unlignified G-layers of poplar, then the mesoporosity disappears with lignification (Chang 2014).

Lignin does not seem to contribute significantly to the generation of maturation stress in tension wood whereas it represents a higher carbon cost for the tree compared to unlignified G-layers. This opens the question of the function of lignin in tension wood. One possible function is that the deposition of lignin "freezes" the maturation stress, preventing its relaxation on the long term. Other hypotheses can be formulated for the function of tension wood. It is known that tension wood has lower compressive strength than normal wood in poplar (Fang et al. 2008) but does not significantly differ from normal wood in nine tropical species (Ruelle et al. 2007a). Lignification may be a way to build a wood with the active contractile properties of tension wood without reduction in compressive strength. Lignin is also known to improve wood resistance against biological aggressions (Baum et al. 2000), and lignification may be a way to build stems more durable than those with unlignified tension wood.

\subsection{Tension wood vs. bark: two divergent strategies}

Our results show that both tension wood and bark can be the motor of the up-righting movement of stems. Results of the debarking experiment show 3 types of species according to the value of debarking curvature: a negative value indicates that bark was promoting the up-righting movement, a positive value shows that bark impeded the up-righting movement, and a value close to zero shows that wood and bark contributed similarly to the up-righting movement. In species with a positive value, our experiments cannot conclude whereas bark generates tensile stress or not, but only shows that if any, bark contribution is not enough to accompany the wood action.

Figure 9 shows the relationship between standardized debarking curvature and stem gravitropic efficiency. It clearly separates species with G-layers from species without G-layers. The former use mainly tension wood as a motor and therefore have a positive debarking curvature. The latter use mainly bark as a motor and have a negative debarking curvature. Most of latter species correspond to those in which the maturation strain of tension wood is low (Table 2), showing they use almost exclusively bark as a motor.

For each set of points, the slope of the relationship is significant $(P<0.001$ for group "No G-layer", $P<0.05$ for group "G-layer") while the intercept is not significantly different from zero $(P>$ 0.05 ), suggesting proportional relationships. Actually, a proportional relationship is expected in the two situations where only one motor is involved. If the only motor is bark, then it is expected that the change in curvature during debarking is the opposite of the change in curvature when releasing the stem from the stake, leading to proportionality between the two standardized parameters. If the only motor is wood, the increase in curvature during debarking is proportional to the change in curvature when releasing the stem from the stake, and the proportionality coefficient depends on the relative contribution of bark to the stem bending stiffness. It leads to proportionality between the two standardized parameters, but with a different slope. These theoretical proportional relationships are illustrated on Fig. 9 for both anatomical groups. Note that the two cases are not identically conclusive. For species without Glayer, values of the maturation strain of tension wood are close to those of normal wood, indicating that these species use almost exclusively bark as a motor. By contrast, for species with G-layers, although our data indicate that the G-layer is a strong motor and that bark partly impedes the up-righting movement, we cannot conclude that the G-layer is the only motor. It is possible that bark is also active (although less than wood) and thus reduces its impeding effect on wood.

A few species (Hevea guianensis, Simarouba amara, Licania macrophylla, Virola michelii) have standardized debarking curvature close to zero, and therefore do not follow any of the two main trends. These are either species with no Glayer where the maturation strain of tension wood is relatively high, or species with G-layer that also use bark as a motor (Table 2). Interestingly, these species have generally a lower gravitropic efficiency than species mainly based on a single mechanism. This strongly suggests that although it is not impossible to use both motors, this solution is sub-optimal. Instead of adding the two actions, there seems to be a tradeoff that reduces overall efficiency. This is likely explained by different requirements regarding the action of wood associated to the two mechanisms. For tension wood to be the motor, a strong tensile stress must be set by wood maturation. This is achieved through the differentiation of G-layers. For bark to be an efficient motor, growing wood must set radial compressive stress against the bark in order to stress it. In species without G-layer, wood fibres are often replaced by swollen parenchyma cells (Clair et al. 2019) that may help generating the required radial compression.

\subsection{Terminology of tension wood}

The term "tension wood" points to the high tensile longitudinal stress induced by the maturation of wood typically produced on the upper side of leaning stems of angiosperm (Fournier et al. 2014). It is opposed to the term "compression wood", referring to wood produced by gymnosperms on the lower side of a leaning axis, inducing longitudinal compressive stress during maturation. Here we see that we reached the limit of the terminology. Most species we studied form wood under strong tensile stress on the upper side. But here we evidenced that in Pachira aquatica and some other species, the wood formed on the upper side of leaning young angiosperms is in a mechanical state at the magnitude of normal wood, or even in light compressive stress in some individuals. Therefore, diversity of species makes old terminology no 


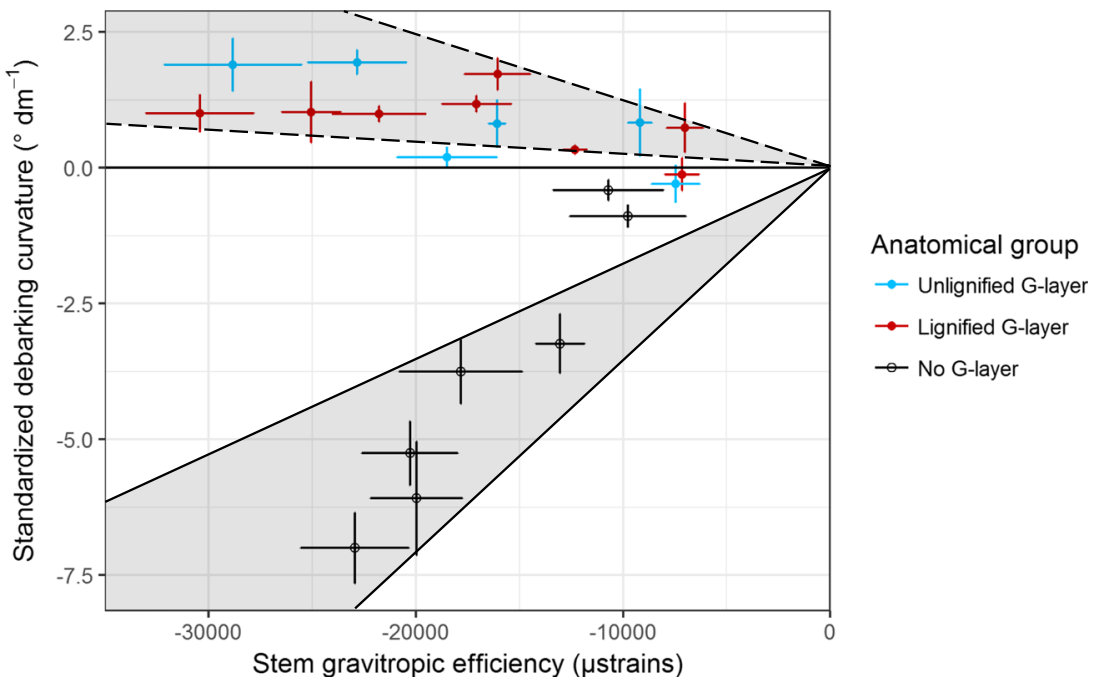

Fig. 9 Inter-specific relationship between standardized debarking curvature and stem gravitropic efficiency for each anatomical group. Dots and error bars represent mean values and standard error for each species. Grey zones illustrate the proportional relationship expected if only one motor is involved. Plain line, the only motor is bark. Dotted line, the only motor is wood. Position and width of the cone are arbitrary set to englobe most experimental points. Width of the cone reflects the expected dispersion linked to the relative contribution of wood and bark to the stem bending stiffness more sufficient. Wood produced on the upper side of these angiosperm species in response to a gravitropic stimulus cannot be termed "tension wood", since it does not act in producing high tension. It would be more accurate to talk about reaction wood as it is, in most species, strongly modified compared to normal wood, but its main action is to generate radial compression through strong radial growth, in order to induce longitudinal stress in the bark.

Acknowledgements We thank Jocelyn Cazal, Soepe Koese and Onoefe NGuete for their help to this study. Saplings of Hevea guianensis and Theobroma cacao were provided by the Centre de Ressources Biologiques, Plantes Pérennes en Guyane (CRB-PPG, CIRAD).

Data availability statement The datasets generated during and/or analysed during the current study are available in the Data INRA repository (Ghislain et al. 2019) at https://doi.org/10.15454/DU1O18.

Funding This work was supported by the French National Research Agency in the framework of the project "StressInTrees" (ANR-12BS09-0004). BG benefits from an "Investissements d'Avenir" grant managed by French National Research Agency (CEBA, ANR-10-LABX-25$01)$.

\section{Compliance with ethical standards}

Declaration on conflict of interest We declare that we have no conflict of interest.

Open Access This article is distributed under the terms of the Creative Commons Attribution 4.0 International License (http:// creativecommons.org/licenses/by/4.0/), which permits unrestricted use, distribution, and reproduction in any medium, provided you give appropriate credit to the original author(s) and the source, provide a link to the Creative Commons license, and indicate if changes were made.

\section{References}

Alméras T, Clair B (2016) Critical review on the mechanisms of maturation stress generation in trees. J R Soc Interface 13:20160550. https://doi.org/10.1098/rsif.2016.0550

Alméras T, Fournier M (2009) Biomechanical design and long-term stability of trees: morphological and wood traits involved in the balance between weight increase and the gravitropic reaction. J Theor Biol 256:370-381. https://doi.org/10.1016/j.jtbi.2008.10.011

Alméras T, Thibaut A, Gril J (2005) Effect of circumferential heterogeneity of wood maturation strain, modulus of elasticity and radial growth on the regulation of stem orientation in trees. Trees 19: 457-467. https://doi.org/10.1007/s00468-005-0407-6

Alméras T, Derycke M, Jaouen G, Beauchêne J, Fournier M (2009) Functional diversity in gravitropic reaction among tropical seedlings in relation to ecological and developmental traits. J Exp Bot 60: 4397-4410. https://doi.org/10.1093/jxb/erp276

Alméras T, Ghislain B, Clair B, Secerovic A, Pilate G, Fournier M (2018) Quantifying the motor power of trees. Trees 32:689-702. https://doi. org/10.1007/s00468-018-1662-7

Angyalossy V, Pace MR, Evert RF et al (2016) IAWA list of microscopic bark features. IAWA J 37:517-615. https://doi.org/10.1163/ 22941932-20160151

Archer RR (1986) Growth stresses and strains in trees. Springer, Berlin Heidelberg

Baum S, Schwarze FWMR, Fink S (2000) Persistence of the gelatinous layer within altered tension-wood fibres of beech degraded by Ustulina deusta. New Phytol 147:347-355. https://doi.org/10. 1046/j.1469-8137.2000.00706.x

Böhlmann D (1971) Zugbast bei Tilia cordata Mill. Holzforschung 25:14. https://doi.org/10.1515/hfsg.1971.25.1.1

Chang SS (2014) Study of macromolecular and structural modifications occurring during the building of the tension wood cell wall : a contribution to the understanding of the maturation stress generation in trees. Thesis, Université de Montpellier 2

Chang S-S, Quignard F, Alméras T, Clair B (2015) Mesoporosity changes from cambium to mature tension wood: a new step toward the 
understanding of maturation stress generation in trees. New Phytol 205:1277-1287. https://doi.org/10.1111/nph.13126

Clair B, Ruelle J, Beauchêne J et al (2006) Tension wood and opposite wood in 21 tropical rain forest species. 1. Occurrence and efficiency of G-layer. IAWA J 27:329-338

Clair B, Alméras T, Pilate G, Jullien D, Sugiyama J, Riekel C (2011) Maturation stress generation in poplar tension wood studied by synchrotron radiation microdiffraction. Plant Physiol 155:562-570. https://doi.org/10.1104/pp.110.167270

Clair B, Ghislain B, Prunier J et al (2019) Mechanical contribution of secondary phloem to postural control in trees: the bark side of the force. New Phytol 221:209-217. https://doi.org/10.1111/nph.15375

Core Team R (2016) R: a language and environment for statistical computing. R Foundation for Statistical Computing, Vienna

Côté WA, Day AC, Timell TE (1969) A contribution to the ultrastructure of tension wood fibers. Wood Sci Technol 3:257-271. https://doi. org/10.1007/BF00352301

Coutand C, Fournier M, Moulia B (2007) The gravitropic response of poplar trunks: key roles of prestressed wood regulation and the relative kinetics of cambial growth versus wood maturation. Plant Physiol 144:1166-1180. https://doi.org/10.1104/pp.106.088153

Dadswell HE, Wardrop AB (1955) The structure and properties of tension wood. Holzforschung 9:97-104. https://doi.org/10.1515/hfsg.1955. 9.4.97

Fang C-H, Gril J, Clair B, Liu S-Q (2008) Growth stresses are highly controlled by the amount of G-layer in poplar tension wood. IAWA J 29:237-246. https://doi.org/10.1163/22941932-90000183

Fisher JB, Mueller RJ (1983) Reaction anatomy and reorientation in leaning stems of balsa (Ochroma) and papaya (Carica). Can J Bot 61:880-887. https://doi.org/10.1139/b83-097

Fisher JB, Stevenson JW (1981) Occurrence of reaction wood in branches of dicotyledons and its role in tree architecture. Bot Gaz 142:82-95. https://doi.org/10.1086/337199

Fournier M, Alméras T, Clair B, Gril J (2014) Biomechanical action and biological functions. In: Gardiner B, Barnett J, Saranpää P, Gril J (eds) The biology of reaction wood. Springer, Berlin, pp 139-169

Ghislain B, Clair B (2017) Diversity in the organisation and lignification of tension wood fibre walls - a review. IAWA J 38:245-265. https:// doi.org/10.1163/22941932-20170170

Ghislain B, Alméras T, Prunier J, Clair B (2019) Dataset of contributions of bark and tension wood and role of the G-layer lignification in the gravitropic movements of 21 tropical tree species. V1. Portail Data INRA. [Dataset]. https://doi.org/10.15454/DU1O18

Gorshkova T, Mokshina N, Chernova T, Ibragimova N, Salnikov V, Mikshina P, Tryfona T, Banasiak A, Immerzeel P, Dupree P, Mellerowicz EJ (2015) Aspen tension wood fibers contain $\beta-(1 \rightarrow$ 4)-galactans and acidic arabinogalactans retained by cellulose microfibrils in gelatinous walls. Plant Physiol 169:2048-2063. https:// doi.org/10.1104/pp.15.00690
Guedes FTP, Laurans F, Quemener B, Assor C, Lainé-Prade V, Boizot N, Vigouroux J, Lesage-Descauses MC, Leplé JC, Déjardin A, Pilate G (2017) Non-cellulosic polysaccharide distribution during G-layer formation in poplar tension wood fibers: abundance of rhamnogalacturonan I and arabinogalactan proteins but no evidence of xyloglucan. Planta 246:857-878. https://doi.org/10.1007/s00425017-2737-1

Jourez B, Riboux A, Leclercq A (2001) Anatomical characteristics of tension wood and opposite wood in young inclined stems of poplar (Populus euramericana cv "Ghoy"). IAWA J 22:133-157

Moulia B, Coutand C, Lenne C (2006) Posture control and skeletal mechanical acclimation in terrestrial plants: implications for mechanical modeling of plant architecture. Am J Bot 93:1477-1489. https:// doi.org/10.3732/ajb.93.10.1477

Okuyama T, Yamamoto H, Yoshida M et al (1994) Growth stresses in tension wood: role of microfibrils and lignification. Ann Sci For 51: 291-300. https://doi.org/10.1051/forest:19940308

Onaka F (1949) Studies on compression and tension wood. Wood Res:188

Pilate G, Chabbert B, Cathala B et al (2004a) Lignification and tension wood. C R Biol 327:889-901. https://doi.org/10.1016/j.crvi.2004. 07.006

Pilate G, Déjardin A, Laurans F, Leplé J-C (2004b) Tension wood as a model for functional genomics of wood formation. New Phytol 164: 63-72. https://doi.org/10.1111/j.1469-8137.2004.01176.x

Roussel J-R, Clair B (2015) Evidence of the late lignification of the Glayer in Simarouba tension wood, to assist understanding how nonG-layer species produce tensile stress. Tree Physiol 35:1366-1377. https://doi.org/10.1093/treephys/tpv082

Ruelle J, Beauchene J, Thibaut A, Thibaut B (2007a) Comparison of physical and mechanical properties of tension and opposite wood from ten tropical rainforest trees from different species. Ann For Sci 64:503-510. https://doi.org/10.1051/forest:2007027

Ruelle J, Yamamoto H, Thibaut B (2007b) Growth stresses and cellulose structural parameters in tension and normal wood from three tropical rainforest angiosperm species. BioResources 2:235-251

Yamamoto H (1998) Generation mechanism of growth stresses in wood cell walls: roles of lignin deposition and cellulose microfibril during cell wall maturation. Wood Sci Technol 32:171-182. https://doi.org/ 10.1007/BF00704840

Zajączkowska U, Kozakiewicz P (2016) Interaction between secondary phloem and xylem in gravitropic reaction of lateral branches of Tilia cordata Mill. trees. Holzforschung 70:993-1002. https://doi.org/10. 1515/hf-2015-0230

Publisher's note Springer Nature remains neutral with regard to jurisdictional claims in published maps and institutional affiliations. 